\title{
DURATION OF PSYCHIATRIC APPOINTMENTS FOR PATIENTS WITH PSYCHOSIS SPECTRUM DISORDERS IN SERBIA - IS IT SIGNIFICANTLY PROLONGED BY DIALOG+ PSYCHOSOCIAL INTERVENTION?
}

\author{
Ivan Ristić ${ }^{1,2}$, Sanja Andrić Petrovićc ${ }^{1,2}$, Stefan Jerotić1,2, \\ Mirjana Zebić ${ }^{1,2}$, Nikolina Jovanovićc ${ }^{3}$, Nađa P. Marićc ${ }^{1,4}$
}

\author{
${ }^{1}$ University of Belgrade, Faculty of Medicine, Belgrade, Serbia \\ ${ }^{2}$ Clinic for Psychiatry, Clinical Centre of Serbia, Belgrade, Serbia \\ ${ }^{3}$ Queen Mary University of London, Unit for Social and \\ Community Psychiatry - WHO Collaborating Centre for \\ Mental Health Services Development, London, United Kingdom \\ ${ }^{4}$ Institute of Mental Health, Belgrade, Serbia
}

\begin{abstract}
Despite national and international guidelines recommending inclusion of psychotherapy and psychosocial interventions as regular part of treatment for patients with psychosis spectrum disorders (PSD), outpatient psychiatric care in Southeastern Europe (SEE) is mostly limited to medication prescription. DIALOG+ is a recently developed technology-based, patient centered psychosocial intervention that provides an economically viable intervention for treatment and comprehensive evaluation of multiple life domains. Its effectiveness in a range of psychiatric disorders has been shown in several studies conducted in high-income countries. Before an ongoing study evaluating DIALOG+ implementation and effectiveness in developing SEE countries is completed, we aimed to explore general impressions of mental health clinicians towards such an intervention and to compare the duration of treatment as usual (TAU) with DIALOG+ enriched appointments of PSD outpatients. The attendees of the national professional educational symposium were presented with DIALOG+, after which they completed a short survey on their general impressions towards the intervention. To obtain the information regarding duration of psychiatric appointments for patients with PSD in Serbia, we used data from a currently ongoing randomized clinical trial where DIALOG+ is being tested for effectiveness. The impressions of the survey $(n=110)$ from mostly psychiatrists and psychiatry residents towards the concept of this intervention were overwhelmingly positive. However, the question arose if TAU is being prolonged by DIALOG+ to the extent that might limit its implementation. Although significant difference in average session duration was observed between DIALOG+ and TAU (31.96 \pm 16.47 vs. $19.75 \pm 6.11$ minutes, $\mathrm{p}<0.01$ ), providing structured interventions and patient evaluation might be of additional benefit for long term care and quality of life of PSD patients. To the best of our knowledge, this was the first evaluation of the duration of psychiatric appointments for outpatients with PSD in Serbia. Present information could be useful for different stakeholders in education of MH workers and implementation of DIALOG+ in the local settings.
\end{abstract}

Key words: Psychosis, psychosocial intervention, therapy, technology, duration 


\section{Introduction}

Psychosis spectrum disorders (PSD) are among the most burdensome and costly illnesses worldwide [1,2] and require comprehensive and longterm treatment. Although pharmacological therapy has been the mainstay of treatment since the introduction of antipsychotics in the 1950s, there has been growing recognition of the importance of psychosocial interventions in the treatment of PSD over the past decades [3]. According to contemporary national and international guidelines for treatment of patients with PSD, psychotherapy and psychosocial interventions should be a regular part of their treatment management [4], alongside pharmacotherapy. Moreover, Serbian guidelines [5] propose that the outcome of non-pharmacological intervention in patients with schizophrenia should be systematically evaluated (in different domains, with patient's satisfaction as one of the major domains for the assessment). Such an approach is recommended, but its feasibility and implementation could be missing.

Systems of outpatient psychiatric care in Southeastern Europe (SEE), as well as in Serbia, offer mental health (MH) care usually limited to the prescription of medications [6]. According to the World Health Organization (WHO) atlas from 2014, the number of psychiatrists in Serbia is 7-8 per 100 000 population, and the number of $\mathrm{MH}$ nurses 12 per 100000 population - a relatively small number in comparison to well-developed European countries (e.g. France with 14 psychiatrists and $90 \mathrm{MH}$ nurses per 100000 population, United Kingdom with 14 psychiatrists and $67 \mathrm{MH}$ nurses per 100000 population, Slovenia with 10 psychiatrists and $90 \mathrm{MH}$ nurses per 100000 population) [7]. This condition could affect outpatient care in psychiatry in different ways (duration of an appointment, type of care, etc.) and could pose a limit for comprehensive treatment of a large proportion of mental health outpatients. PSD patients could be at risk of limited outpatient psychiatric care as well.

A new technology-based, patient centered intervention, based on the principles of solution focused therapy, DIALOG+, has recently been developed in order to provide an accessible, effective and economically viable intervention for psychiatric patients. Other than being used for the treatment, it is also a useful tool for evaluation of multiple life domains. Using this psychosocial intervention, clinicians can comprehensively screen mental, physical and social problems of patients and plan actions in related domains areas (8). Mechanisms of its action include active patient involvement in care and empowerment, mobilization of social resources, self-reflection and therapeutic expression. In each session, patients use a tablet to rate their satisfaction with eight life domains (mental health, physical health, job situation, accommodation, leisure activities, friendships, relationship with family/partner and personal safety) and three treatment aspects (medication, practical help and meetings with professionals). Each satisfaction item is rated on a scale. The ratings are followed by a four-step solution-focused approach to identify 
the patient's existing resources that can be used to address the concerns raised, followed by agreeing on actions (e.g. homework and referrals) [8].

DIALOG+ effectiveness has been shown in high-income countries in several studies where it increased quality of life and reduced symptomatology in a range of disorders, including PSD [9-12]. With approximately three hours of training, clinical staff involved in $\mathrm{MH}$ care (e.g. nurses, psychologists and psychiatrists) in the UK was able to successfully implement the intervention in routine practice [11].

It is currently unknown how local factors in developing countries may influence implementation and effectiveness of psychosocial interventions such as DIALOG+. Before an ongoing implementation and effectiveness study sought to evaluate DIALOG+ in such a setting is completed, we were interested to explore general impressions of $\mathrm{MH}$ clinicians towards such an intervention. Since we hypothesized that delivering DIALOG+ intervention might influence the duration of routine psychiatric appointments, our secondary aim was to compare the duration of treatment as usual (TAU) with DIALOG+ enriched appointments of PSD outpatients.

\section{Methods}

The sample

The survey was conducted during the 45th Educational Symposium of the Clinic for Psychiatry (18-19 Nov 2018) in Belgrade, Serbia. After attending a 30-minute-long presentation about the DIALOG+ in Serbian language by one of the authors of this study (NM), participants of the symposium were asked to complete a short survey on their general impressions towards the aforementioned psychosocial intervention. This was the first time DIALOG+ was presented in Serbia.

\section{Survey}

The survey was developed by the authors of the study. In the first part of the survey, MH professionals were asked to fill out basic sociodemographic and clinical information (age, gender, profession, years of working experience in $\mathrm{MH}$, additional training in any psychotherapy, number of patients treated per week).

The second part of the survey consisted of five single choice questions regarding the initial impressions towards DIALOG+, difference between DIALOG+ and regular outpatient appointments, possible difficulties in learning DIALOG+, about incorporating DIALOG+ in their regular clinical appointments and the impressions about whether other colleagues would be interested in using DIALOG+.

The third part of the survey consisted of 3 multiple-choice questions where the $\mathrm{MH}$ professionals were asked to identify the criteria for patient selection for DIALOG+, people who would benefit the most from DIALOG+ 
and potential obstacles for implementation of DIALOG+ in everyday (routine) practice.

\section{Duration of sessions}

To obtain information about the duration of psychiatric appointments for patients with PSD in Serbia, we used data from a currently ongoing randomized clinical trial (RCT) where DIALOG+ is currently being tested for effectiveness. This study is a part of a larger implementation and effectiveness hybrid 2 type study called IMPULSE [8]. Sixteen clinicians from two different centers (Clinic for Psychiatry in Belgrade and Special Psychiatric Hospital in Vršac) were randomized into two groups. One group provided treatment as usual (TAU) and the other provided DIALOG+ enriched outpatient sessions. These two centers offer well-developed psychiatric services, are operated by the government and are contracted with the National Health Insurance Fund of Serbia (NHIF).

Psychiatric appointments took place at outpatient clinics between April and May 2019 and involved clinically stable patients with primary diagnosis of PSD (ICD F20-F29 and F31). The clinicians providing the DIALOG+ intervention were previously trained by the IMPULSE study research team. Both groups received short instructions on how to follow the patients through the trial and were instructed to note down session times. The TAU group was instructed not to change their routine practice. A total of 6 visits were planned over the span of 12 months. In order to evaluate the duration of psychiatric appointments for the present study, we collected data from the second and third appointments for both the intervention and TAU group (the first visit was not taken into consideration due to the additional time needed for the patient and clinician to get comfortable with the new intervention).

The RCT was conducted in accordance with the Declaration of Helsinki and its design was approved by the Medical Ethics Committee of the Faculty of Medicine University of Belgrade, as well as by the professional boards of the both study sites.

\section{Data analysis}

Differences in continuous variables between the patient groups were evaluated using the t- test for independent samples. Chi-square test was used to determine the differences in non-parametric variables. Values of "p" less than 0.05 were deemed as statistically significant.

\section{Results}

Participants

A total of 130 questionnaires were handed out. Out of one hundred and ten participants who filled out the survey (84.6\% response rate), most were psychiatrists and psychiatry residents. Their demographic characteristics and information about clinical practice are given in Table 1. 
Table 1. Demographic characteristics and clinical practice information of the sample

\begin{tabular}{|c|c|c|}
\hline \multirow[t]{4}{*}{ Profession (\%) } & M.D. - Specialist in psychiatry & 76.4 \\
\hline & M.D. - Resident & 18.2 \\
\hline & MH Nurse & 3.6 \\
\hline & Social worker & 1.8 \\
\hline \multicolumn{2}{|c|}{ Additional training in any psychotherapy (yes \%) } & 50 \\
\hline \multicolumn{2}{|c|}{ Gender (\% female) } & 80.7 \\
\hline \multicolumn{2}{|c|}{ Age $($ mean \pm SD $)$} & $48.3 \pm 10.8$ \\
\hline & ice in psychiatry $($ mean $\pm S D)$ & $17.6 \pm 11.2$ \\
\hline \multicolumn{2}{|c|}{ Number of $M H$ patients weekly $($ mean \pm SD) } & $46.1 \pm 26.7$ \\
\hline
\end{tabular}

Attitudes and impressions

The majority of participants expressed positive general impressions regarding DIALOG+ and interest in receiving training in the aforementioned psychosocial intervention (detailed information is given in Table 2). Eightythree percent of participants considered DIALOG+ useful for mental health care receivers, $60.7 \%$ for mental health care providers, $12.1 \%$ for mental health care managers, while $1.4 \%$ chose other.

Table 2. General impressions towards DIALOG+

\begin{tabular}{|l|r|r|r|r|}
\hline & $\mathbf{n}$ & Positive\% & Negative\% & $\begin{array}{r}\text { Not } \\
\text { sure \% }\end{array}$ \\
\hline $\begin{array}{l}\text { 1. What is your first impression with } \\
\text { DIALOG+ }\end{array}$ & 110 & 90.9 & 1.8 & 7.3 \\
\hline $\begin{array}{l}\text { 2. Is DIALOG+ similar to usual } \\
\text { outpatient appointments or if not, } \\
\text { could you easily adapt to it? }\end{array}$ & 110 & 80.0 & 4.5 & 15.5 \\
\hline $\begin{array}{l}\text { 3. Do you think you would have an } \\
\text { easy time using DIALOG+? }\end{array}$ & 110 & 90.9 & 0.9 & 8.2 \\
\hline $\begin{array}{l}\text { 4. Would your colleagues be } \\
\text { 5. interested in using DIALOG+? }\end{array}$ & 109 & 60.6 & 1.8 & 37.6 \\
\hline $\begin{array}{l}\text { 6. Would you be interested in } \\
\text { receiving training in DIALOG+? }\end{array}$ & 74 & 82.4 & 17.6 & 0 \\
\hline
\end{tabular}

The survey participants identified patients' motivation and diagnosis as the most important criteria for the selection of subjects suitable for DIALOG+, followed by their personality characteristics (see Figure 1). As the biggest obstacle in providing DIALOG+, participants pointed out the lack of designated time per patient (see Figure 2). 


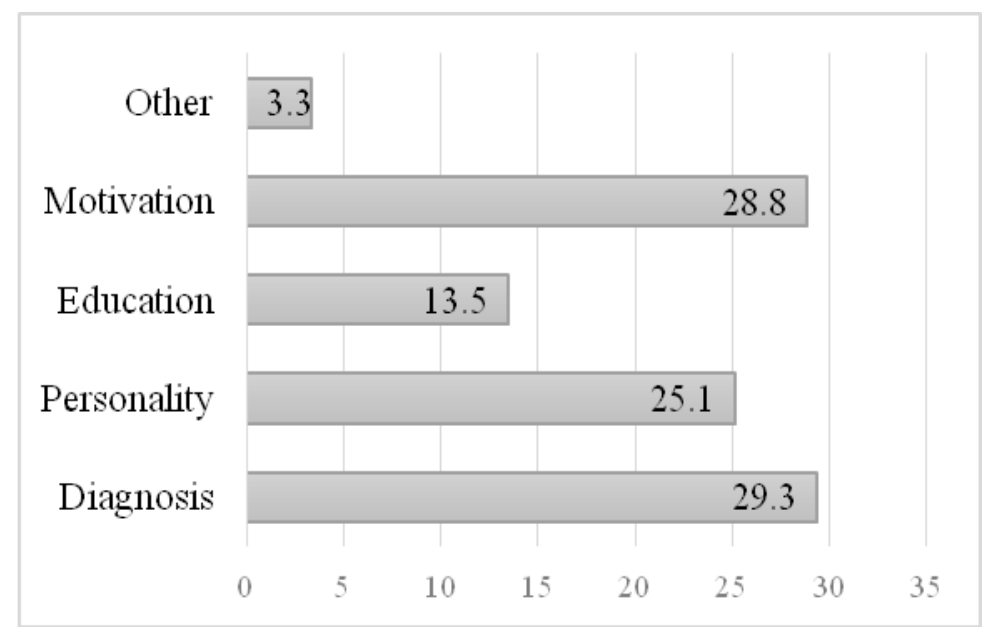

Figure 1. Criteria for choosing patients for DIALOG+ intervention (\% of responses)

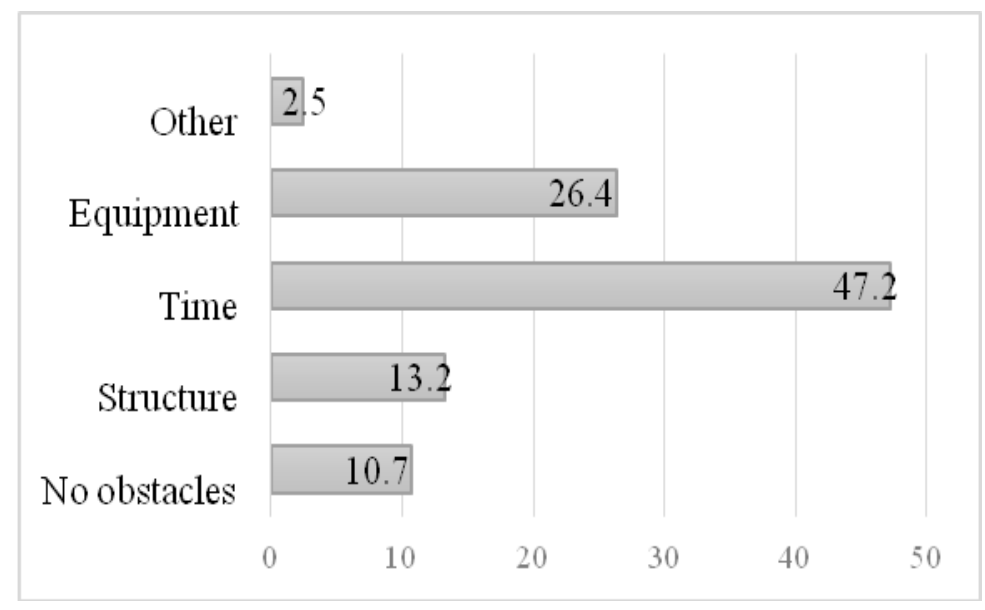

Figure 2. Obstacles for DIALOG+ implementation (\% of responses)

\section{Duration of sessions}

A total of 150 sessions were taken into consideration when evaluating its duration (74 DIALOG+ sessions, 76 TAU sessions). There were no statistically significant differences between the patients in both groups in terms of gender $(58.5 \%$ male in DIALOG+ group, $51.3 \%$ male in TAU group; $\left.\chi^{2}=0.425, \mathrm{p}=0.51\right)$ and diagnosis $\left(\chi^{2}=8.022, \mathrm{p}=0.23\right)$. There was a statistically significant difference between the groups in age (mean age for DIALOG+ group 47.34 \pm 11.14 , TAU group 40.51 $\pm 11.06 ; \mathrm{t}=2.75, \mathrm{p}=0.007$ ).

The average DIALOG+ session lasted $31.96 \pm 16.47$ minutes, while the average TAU session lasted $19.75 \pm 6.11$ minutes. There was a statistically significant difference in the duration of sessions between the two groups ( $\mathrm{t}=6.051, \mathrm{p}<0.01$, Cohen's $d=0.98$ ). 


\section{Discussion}

The participants of this survey were MDs in most of the cases, with around 18 years of experience in $\mathrm{MH}$ and, in half of the cases, trained in psychotherapy during their professional education. After learning about DIALOG+ intervention and getting the first impressions, most of the clinicians (91.9\%) had initial impressions that were overwhelmingly positive. This, together with the finding that over two thirds of the sample thought that they would not have a difficult time adapting to the intervention allows an optimistic attitude going forwards in the process of implementation locally.

Most of the clinicians noted that the best criteria for choosing patients for DIALOG+ were by patient's motivation and diagnosis. An earlier review of literature found that motivation was indeed a factor that could influence the outcome of psychotherapy [13]. DIALOG+ has so far been found effective in a range of diagnoses [11,12], but we are yet to know whether this applies to the local context in middle-income SEE countries.

The biggest obstacles as noted by the clinicians was the time necessary for DIALOG+ sessions. This may be interpreted as a shortcoming of the health care systems in low- and middle- income countries, but it is nevertheless an obstacle for implementation of an intervention that does require additional time for ambulatory visits.

Although psychiatry has been viewed as the most time-intensive medical specialty with major importance of appointment length [14] brief medication management appointments - lasting 15 to 20 minutes, are becoming the principal clinical service provided during outpatient care. According to the National Ambulatory Medical Care Survey (2006), the visit duration for psychiatrists was around $32 \mathrm{~min}$, with very large variations $\left(25^{\text {th }}\right.$ percentile was $19 \mathrm{~min}$, while $75^{\text {th }}$ percentile was $44 \mathrm{~min}$ ) [15]. Another study from the United States found that the average outpatient visit lasted $30.5 \pm 1.2$ minutes [16]. A study of national trends in psychotherapy in the United States noticed a declining trend of psychotherapy visits (defined as lasting longer than 30 minutes) between 1997 and 2005 [17]. A study exploring the underlying reasons for low appointment adherence found that the average outpatient appointment length was $22 \pm 12$ minutes (ranging from 4-60 minutes) and that appointment length was not significantly associated with appointment adherence [14].

Different factors might influence the duration of outpatient visits in the local context. Considering how nurses are only involved in the administrative part of scheduling outpatient visits, much of the workload falls onto the psychiatrists themselves, including paperwork. The main assignment of psychologists is diagnostics and rarely psychotherapy, leading to an increase of patients per psychiatrist.

To the best of our knowledge, this is the first evaluation of the duration of psychiatric appointments for outpatients with psychotic disorders in 
Serbia. Even though the duration of sessions in our trial was significantly longer in the DIALOG+ group, providing structured intervention as well as patient evaluation might be of additional benefit for long term care of PSD patients [12], which could also affect quality of life and has overall positive cost/benefit outcome.

Comprehensive evaluation of patient's current state, instead of brief unstructured visits, is important in long-term treatment and care. Slade et al. (2006) have noted that gathering outcome data from a procedure that is meaningful and beneficial for the patients has a higher likelihood of succeeding when compared to methods of evaluation outside of the clinical appointments [18]. It has been proven that, in the long term, more structured methodology used in psychosocial interventions outweighs the importance of unstructured, individual-based methods [12]. Furthermore, a recent case-control study of Fernholm et al. [19] found that patients with psychiatric illness are at higher risk of preventable harm in primary care and the emergency department, meaning that additional evaluation could prove useful in minimizing avoidable consequences.

This study had certain limitations. The survey used in the study was designed by the authors of the study and was not previously standardized. We did not ask the participants for detailed data that might have been useful (particular diagnoses that DIALOG+ could be useful for, noting down which things are different from usual appointments, etc.). The number of patients per MH professional had a large range, possibly because of the way the question was phrased (it may have been interpreted as the total number of outpatients in their clinic). Unlike DIALOG+ sessions, where the information about duration of sessions was taken through a tablet, TAU session durations were reported by the clinicians and may not have been completely accurate. Finally, underrepresentation of psychologists, which are important providers of non-pharmacological MH care, represents an obstacle which should be overcome in the future.

\section{Conclusions}

In line with international and national guidelines, structured patientclinician communication in psychosocial interventions could be beneficial for psychosis spectrum patients during the maintenance phase of therapy and should be used by MH professionals. Experiences from the UK showed that DIALOG+ could provide an accessible, effective and economically viable psychosocial intervention for psychiatric patients. The first impressions of Serbian clinicians towards the concept of this intervention were overwhelmingly positive, however the question arose if the treatment as usual has been prolonged by DIALOG+ to the extent that has been limiting its implementation. By presenting the data from the survey and the answer to this particular question, we believe that this information could be useful for different stake- 
holders, in the education of $\mathrm{MH}$ workers and in implementation of given psychosocial intervention in the local setting.

\section{Acknowledgement}

This project has received funding from the European Union's Horizon 2020 research and innovation programme under grant agreement No 779334. 


\section{TRAJANJE POSETE PSIHIJATRU TOKOM LEČENJA OSOBA SA PSIHOTIČNIM POREMEĆAJIMA U SRBIJI - DA LI SE ZNAČAJNO PRODUŽAVA PRIMENOM PSIHOSOCIJALNE INTERVENCIJE DIALOG+?}

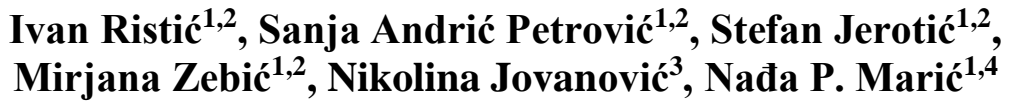

${ }^{1}$ Medicinski fakultet Univerziteta u Beogradu, Beograd, Srbija

${ }^{2}$ Klinika za psihijatriju, Klinički centar Srbije, Beograd, Srbija

${ }^{3}$ Queen Mary University of London, Unit for Social and

Community Psychiatry - WHO Collaborating Centre for

Mental Health Services Development, London, United Kingdom

${ }^{4}$ Institut za mentalno zdravlje, Beograd, Srbija

Apstrakt: Iako nacionalni i međunarodni vodiči preporučuju primenu psihoterapije i psihosocijalnih intervencija u lečenju pacijenata sa psihotičnim spektrom poremećaja (PSD), vanbolničko psihijatrijsko lečenje u Jugoistočnoj Evropi (SEE) je uglavnom ograničeno na propisivanje farmakoterapije. DIALOG+ je nov, tehnološki zasnovan pristup u tretmanu pacijenata sa različitim poremećajima, koji pruža ekonomski isplativu terapijsku intervenciju uz sveobuhvatnu procenu radi poboljšanja adaptivnih mehanizama za svakodnevni život. Efektivnost ove intervencije u više psihijatrijskih poremećaja dokazana je kroz nekoliko studija $u$ ekonomski razvijenim sredinama. Imlementacija i efektivnost DIALOG+ intervencije u SEE je u fazi ispitivanja. Pre završetka ovih ispitivanja, planirali smo da istražimo prve utiske kliničara koji se bave mentalnim zdravljem o ovoj intervenciji, kao i da poredimo trajanje uobičajenih (TAU) i DIALOG+ sesija kod pacijenata sa PSD. DIALOG+ je prezentovan učesnicima na tradicionalnom edukativnom simpozijumu Klinike za Psihijatriju KCS, nakon čega su popunili kratak upitnik o opštim utiscima prema intervenciji. Za prikupljanje podataka o trajanju ambulantnih poseta pacijenata sa PSD u Srbiji su korišćeni podaci iz randomizovane kliničke studije gde se testira efektivnost DIALOG+ intervencije. Upitnik su popunili uglavnom specijalisti i specijalizanti psihijatrije $(n=110)$. Prvi utisci prema konceptu intervencije su bili pretežno pozitivni. Ono što bi mogla biti prepreka za implementaciju je bilo pitanje da li je TAU značajno produžen uvođenjem DIALOG+ intervencije, do mere koja bi mogla da ograniči njegovu implementaciju. Iako postoji značajna razlika u trajanju prosečne ambulantne posete između DIALOG+ i TAU $(31.96 \pm 16.47$ vs. $19.75 \pm 6.11$ minuta, $\mathrm{p}<0.01)$, pružanje strukturisane intervencije i procene pacijenata bi moglo da pruži značajno poboljšanje dugotrajne nege i kvaliteta života pacijenata sa PSD. Ovo je prva procena trajanja ambulantnih poseta pacijenata sa PSD u Srbiji. Dobijene informacije bi mogle biti korisne u edukaciji budućih lekara, svih zainteresovanih zdrastvenih radnika i saradnika, kao i tokom implementacije DIALOG+ intervencije u zemlji i u regionu.

Ključne reči: Psihoza, psihosocijalna intervencija, terapija, tehnologija, dužina 


\section{References}

1. Rössler W, Joachim Salize H, Van Os J, Riecher-Rössler A. Size of burden of schizophrenia and psychotic disorders. Eur Neuropsychopharmacol. 2005;15(4):399-409.

2. Wittchen HU, Jacobi F, Rehm J, Gustavsson A, Svensson M, Jönsson $\mathrm{B}$, et al. The size and burden of mental disorders and other disorders of the brain in Europe 2010. Eur Neuropsychopharmacol [Internet]. Elsevier B.V.; 2011;21(9):655-79. Available from: http://dx.doi.org/10.1016/j.euroneuro.2011.07.018

3. National Institute for Health and Care Excellence (NICE). Psychosis and schizophrenia in adults: prevention and management. Nice. 2014.

4. Lehman AF, Lieberman JA, Dixon LB, McGlashan TH, Miller AL, Perkins DO, et al. Practice Guideline for the Treatment of Patients with Schizophrenia, Second Edition. Vol. 161, American Journal of Psychiatry. 2004.

5. Lečić-Tosevski D (rukovodilac): Nacionalni vodič dobre kliničke prakse za dijagnostikovanje i lečenje shizofrenije. Republička stručna komisija za izradu i implementaciju vodiča u kliničkoj praksi. Ministarstvo zdravlja Republike Srbije, Beograd 2013.

6. Winkler P, Krupchanka D, Roberts T, Kondratova L, Machů V, Höschl C, et al. A blind spot on the global mental health map: a scoping review of 25 years' development of mental health care for people with severe mental illnesses in central and eastern Europe. The Lancet Psychiatry. 2017;4(8):634-42.

7. World Health Organization. (2015). Mental Health Atlas 2014. WHO, Geneva. http://www.who.int/mental_health/evidence/atlas/profiles-2014/en/, [accessed 18.02.20.].

8. Jovanovic N, Francis J, Maric NP, Arenliu A, Barjaktarov S, Kulenovic $\mathrm{AD}$, et al. Implementing a psychosocial intervention DIALOG+ for patients with psychotic disorders in low and middle income countries in South Eastern Europe: protocol for a hybrid effectiveness-implementation cluster randomized clinical trial (IMPULSE). Glob Psychiatry. 2019;0(0):1-14.

9. Omer S, Golden E, Priebe S. Exploring the mechanisms of a patientcentred assessment with a solution focused approach (DIALOG+) in the community treatment of patients with psychosis: A process evaluation within a cluster-randomised controlled trial. PLoS One. 2016;11(2):1-17.

10. Priebe S, Golden E, McCabe R, Reininghaus U. Patient-reported outcome data generated in a clinical intervention in community mental health care - psychometric properties. BMC Psychiatry. 2012;12.

11. Priebe S, Kelley L, Omer S, Golden E, Walsh S, Khanom H, et al. The Effectiveness of a Patient-Centred Assessment with a SolutionFocused Approach (DIALOG+) for Patients with Psychosis: A 
Pragmatic Cluster-Randomised Controlled Trial in Community Care. Psychother Psychosom. 2015;84(5):304-13.

12. Priebe S, McCabe R, Bullenkamp J, Hansson L, Lauber C, MartinezLeal R, et al. Structured patient-clinician communication and 1-year outcome in community mental healthcare: Cluster randomised controlled trial. Br J Psychiatry. 2007;191(11):420-6.

13. Luborsky L, et al. Factors influencing the outcome of psychotherapy: A review of quantitative research. Psychol Bull. 1971;75(3):145-85.

14. Cruz M, Roter DL, Cruz RF, Wieland M, Larson S, Cooper LA, et al. Appointment length, psychiatrists' communication behaviors, and medication management appointment adherence. Psychiatr Serv. 2013;64(9):886-92.

15. Nelson C, Woodwell D. National ambulatory medical care survey: 1993 summary. Vital Heal Stat Ser 13 Data Heal Resour Util. 1998;13(136).

16. Olfson M, Cherry DK, Lewis-Fernández R. Racial differences in visit duration of outpatient psychiatric visits. Arch Gen Psychiatry. 2009;66(2):214-21.

17. Mojtabai R, Olfson M. National trends in psychotherapy by officebased psychiatrists. Arch Gen Psychiatry. 2008;65(8):962-70.

18. Slade M, McCrone P, Kuipers E, Leese M, Cahill S, Parabiaghi A, et al. Use of standardised outcome measures in adult mental health services: Randomised controlled trial. $\mathrm{Br} \mathrm{J}$ Psychiatry. 2006;189(10):330-6.

19. Fernholm R, Holzmann MJ, Wachtler C, Szulkin R, Carlsson AC, Pukk Härenstam K. Patient-related factors associated with an increased risk of being a reported case of preventable harm in first-line health care: A case-control study. BMC Fam Pract. BMC Family Practice; 2020;21(1):1-8.

Prof. dr Nadja P. MARIĆ, Institut za mentalno zdravlje, Medicinski fakultet Univerziteta u Beogradu, Beograd, Srbija

Professor Nadja P. MARIC, Institute of Mental Health, School of Medicine, University of Belgrade, Serbia

E-mail: nadja.maric-bojovic@med.bg.ac.rs 